\title{
Clinical and imaging features of newly recognized Kelch-like protein 11 paraneoplastic syndrome
}

Joshua K. Wong, MD, Jun Yu, MD, Addie Patterson, DO, Aaron Carlson, MD, and Aparna Wagle Shukla, MD Neurology ${ }^{\circledR}$ 2020;95:134-135. doi:10.1212/WNL.0000000000009895

Figure MRI brain at 12 and 20 months after the symptom onset
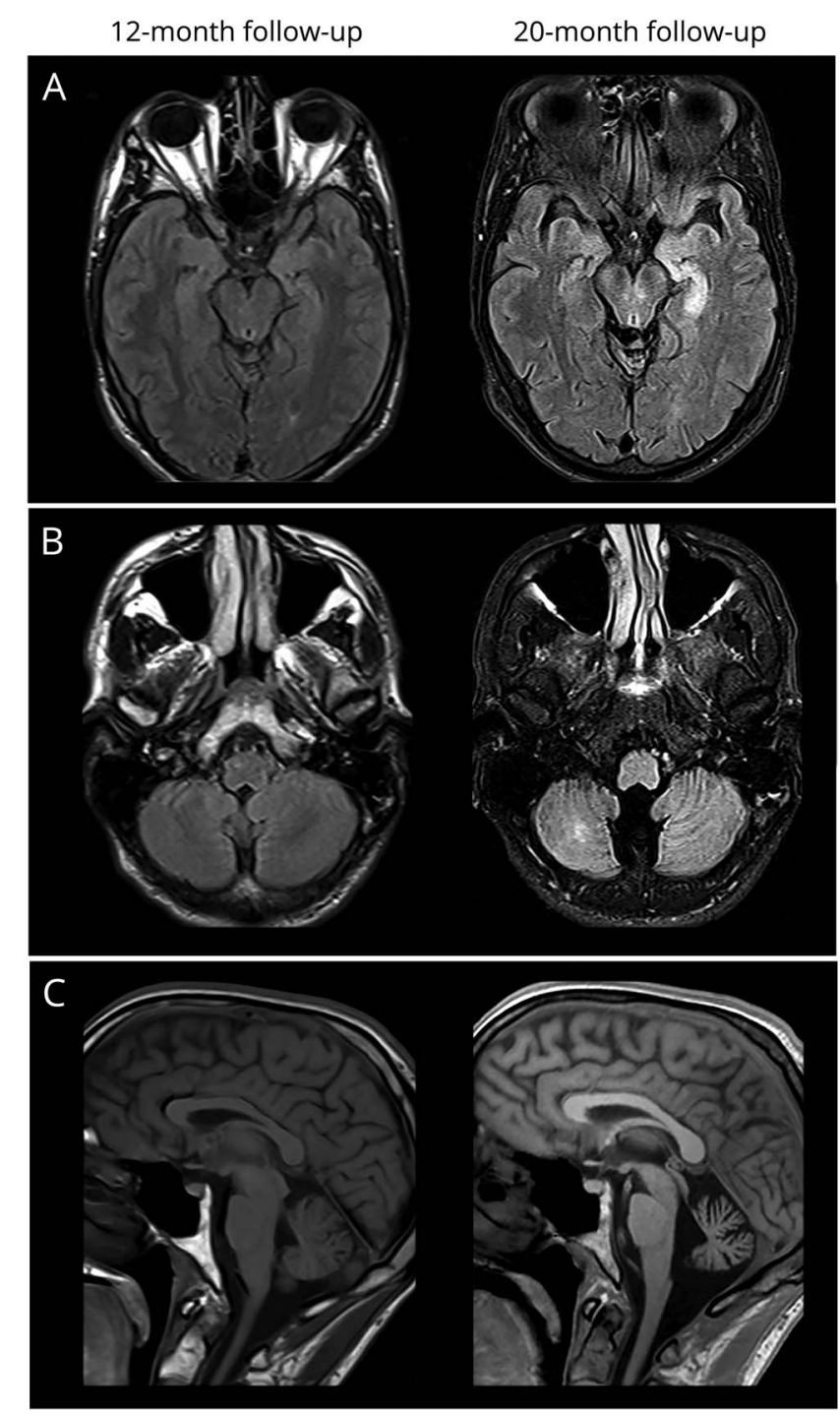

(A, B) Axial T2 fluid-attenuated inversion recovery sequences with progressively worsening left hippocampal and right cerebellar dentate nuclei hyperintensities over time. (C) Rapidly progressive cerebellar atrophy over 8 months in a sagittal T1 sequence.

\section{Correspondence}

Dr. Wong

Joshua.Wong@

neurology.ufl.edu

or Dr. Wagle Shukla

Aparna.Shukla@

neurology.ufl.edu

MORE ONLINE

○ Video 
A 32-year-old man presented with hearing loss and gait difficulties. His symptoms, including double vision, dysarthria, dysphagia, neck posturing, and tremors, evolved rapidly over 9 months. Within 15 months of onset, he used a wheelchair. He experienced no improvement after trials of intravenous methylprednisolone, intravenous immunoglobulins, plasmapheresis, and rituximab. His CSF testing was unrevealing except for elevated proteins and oligoclonal bands. $\mathrm{He}$ underwent serial brain imaging (figure). Extensive laboratory investigations, including nutritional, metabolic, mitochondrial, infectious, autoimmune, and paraneoplastic panels, were unremarkable (video). Expanded tissue-based immunofluorescence testing revealed positive Kelch-like protein $11 \mathrm{im}$ munoglobulin $G$ in the serum, a newly recognized paraneoplastic encephalitis. ${ }^{1,2}$

\section{Acknowledgment}

The authors thank the Mayo Clinic Jacksonville and Mayo Neuroimmunology Laboratory.

\section{Study funding}

No targeted funding reported.

\section{Disclosure}

J.K. Wong's research is supported by the NIH (1R25NS108939). J. Yu, A. Patterson, and A. Carlson report no disclosures relevant to the manuscript. A. Wagle Shukla reports grants from the $\mathrm{NIH}$ and has received grant support from Benign Essential Blepharospasm Research foundation, Dystonia coalition, Dystonia Medical Research foundation, National Organization for Rare Disorders, and grant support from NIH (KL2 and K23 NS092957-01A1); reports receiving honoraria from Acadia, Cavion, Elsevier, and MJFF in the past; and participates as a coinvestigator for several NIH, foundation, and industry sponsored trials over the years but has not received honoraria. Go to Neurology.org/N for full disclosures.

\begin{tabular}{|c|c|c|}
\hline Name & Location & Contribution \\
\hline $\begin{array}{l}\text { Joshua } \\
\text { Wong, MD }\end{array}$ & $\begin{array}{l}\text { Department of Neurology, } \\
\text { Fixel Institute for } \\
\text { Neurological Diseases, } \\
\text { University of Florida, } \\
\text { Gainesville }\end{array}$ & $\begin{array}{l}\text { Designed and conceptualized } \\
\text { study, major role in the } \\
\text { acquisition of data, drafted } \\
\text { the manuscript for } \\
\text { intellectual content }\end{array}$ \\
\hline Jun Yu, MD & $\begin{array}{l}\text { Department of Neurology, } \\
\text { Fixel Institute for } \\
\text { Neurological Diseases, } \\
\text { University of Florida, } \\
\text { Gainesville }\end{array}$ & $\begin{array}{l}\text { Major role in the acquisition } \\
\text { of data, drafted the } \\
\text { manuscript for intellectual } \\
\text { content }\end{array}$ \\
\hline $\begin{array}{l}\text { Addie } \\
\text { Patterson, } \\
\text { DO }\end{array}$ & $\begin{array}{l}\text { Department of Neurology, } \\
\text { Fixel Institute for } \\
\text { Neurological Diseases, } \\
\text { University of Florida, } \\
\text { Gainesville }\end{array}$ & $\begin{array}{l}\text { Major role in the acquisition } \\
\text { of data }\end{array}$ \\
\hline $\begin{array}{l}\text { Aaron } \\
\text { Carlson, } \\
\text { MD }\end{array}$ & $\begin{array}{l}\text { Department of Neurology, } \\
\text { Fixel Institute for } \\
\text { Neurological Diseases, } \\
\text { University of Florida, } \\
\text { Gainesville }\end{array}$ & $\begin{array}{l}\text { Major role in the acquisition } \\
\text { of data }\end{array}$ \\
\hline $\begin{array}{l}\text { Aparna } \\
\text { Wagle } \\
\text { Shukla, } \\
\text { MD }\end{array}$ & $\begin{array}{l}\text { Department of Neurology, } \\
\text { Fixel Institute for } \\
\text { Neurological Diseases, } \\
\text { University of Florida, } \\
\text { Gainesville }\end{array}$ & $\begin{array}{l}\text { Major role in the acquisition } \\
\text { of data, designed and } \\
\text { conceptualized study, revised } \\
\text { the manuscript for } \\
\text { intellectual content }\end{array}$ \\
\hline
\end{tabular}

\section{References}

1. Mandel-Brehm C, Dubey D, Kryzer TJ, et al. Kelch-like protein 11 antibodies in seminoma-associated paraneoplastic encephalitis. N Engl J Med 2019;381:47-54.

2. Maudes E, Landa J, Muñoz-Lopetegi A, et al. Clinical significance of Kelch-like protein 11 antibodies. Neurol Neuroimmunol Neuroinflamm 2020;7:e666.

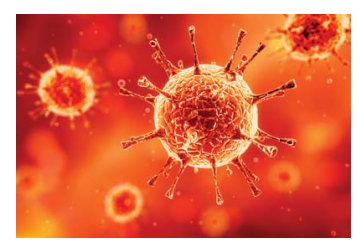

\section{COVID-19 and Neurologic Disease: Call for Papers!}

The editors of Neurology are interested in papers that address the neurological aspects of COVID-19 infection and challenges to the management of patients with chronic neurological conditions who have, or are at risk for, the infection. Relevant papers that pass initial internal review will undergo expedited peer review and online publication. We will consider papers posted in preprint servers.

Submit observational studies and clinical trials as Articles and case series and case reports under the Clinical/Scientific Notes category to https://submit.neurology.org/ today! 


\section{Neurology}

\section{Clinical and imaging features of newly recognized Kelch-like protein 11 paraneoplastic syndrome}

Joshua K. Wong, Jun Yu, Addie Patterson, et al.

Neurology 2020;95;134-135 Published Online before print June 19, 2020

DOI 10.1212/WNL.0000000000009895

This information is current as of June 19, 2020

\section{Updated Information \&} Services

References

Subspecialty Collections

Permissions \& Licensing

Reprints including high resolution figures, can be found at:

http://n.neurology.org/content/95/3/134.full

This article cites 2 articles, 1 of which you can access for free at: http://n.neurology.org/content/95/3/134.full\#ref-list-1

This article, along with others on similar topics, appears in the following collection(s):

Encephalitis

http://n.neurology.org/cgi/collection/encephalitis

Gait disorders/ataxia

http://n.neurology.org/cgi/collection/gait_disorders_ataxia

Paraneoplastic syndrome

http://n.neurology.org/cgi/collection/paraneoplastic_syndrome

Tremor

http://n.neurology.org/cgi/collection/tremor

Information about reproducing this article in parts (figures,tables) or in its entirety can be found online at:

http://www.neurology.org/about/about_the_journal\#permissions

Information about ordering reprints can be found online:

http://n.neurology.org/subscribers/advertise

Neurology ${ }^{\circledR}$ is the official journal of the American Academy of Neurology. Published continuously since 1951, it is now a weekly with 48 issues per year. Copyright (C 2020 American Academy of Neurology. All rights reserved. Print ISSN: 0028-3878. Online ISSN: 1526-632X.

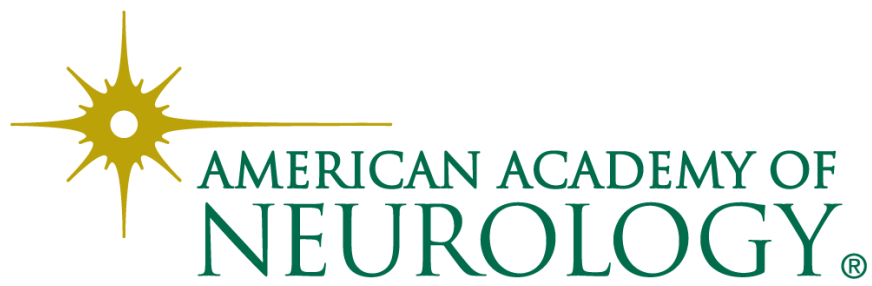

